\title{
Aggregate size measures of merger market: empirical evidence from Poland, 2002-2013
}

\author{
Author: Aleksander Buczek
}

\begin{abstract}
Merger and acquisition activity is very important economic phenomenon often leading to a permanent organizational changes of single industries or even entire economies. Theoretical part of this article is an attempt to define aggregate size measures which allow gaining quantitative view on its dimensions. Four measures are proposed to assess the size of a merger and acquisition market, namely: announced, backlog, completed and withdrawn volumes. Relationship between these measures is introduced. Their accuracy is dependent on assumed transaction and registration announcement definitions. Limitations of the research based on the commercial vendors' datasets (for example Thomson Reuters) are presented. In order to overcome these limitations, alternative data collection methodology for merger transactions is derived from legal consolidation procedure defined in The Code of Commercial Partnerships and Companies. This approach allows collecting the information about 3870 merger transactions which have taken place in the period between 1st January 2002 and 31st December 2013 in Poland. Announced, backlog and completed volumes are calculated quarterly. All these quantitative measure exhibit strong seasonality. Besides, their stable growth on Polish market was observed from 2002 till 2011. After 2011 this trend has reverted, but rebound of the backlog volume in the second quarter of 2013 suggests that at least completed volume levels should be higher in the upcoming quarters.
\end{abstract}

Keywords: Merger and acquisition process; Legal merger procedure; Market size measurement; Polish merger market; Volumes analysis.

\section{Introduction}

Development strategy of every company is always a combination of both
JEL: C81, G34, K20

History: Otrzymano 2015-11-19, poprawiono 2016-06-30, zaakceptowano 2016-07-05

internal and external growth strategies. Internal growth concentrates on investments into company's human capital, infrastructure or research 
and development activities. In turn, external growth aims to gain control over other companies which possess unique resources giving competitive advantage on the market. This latter strategy may be executed as a merger or acquisition transaction.

Across the years, these merger and acquisition transactions became more and more important economic phenomenon often leading to a permanent organizational changes of the single industries or even entire economies. Pryor (2001: 825) states that it is hard to assess the magnitude of this phenomenon without an aggregate quantitative view of its dimensions.

This article is an attempt to provide aggregate size measures which allows gaining such quantitative perspective mentioned by Pryor.

The article is set up as follows. The next section defines various market size measures in the context of merger and acquisition transaction process. The significance of its initialization and termination events is highlighted. As the empirical part concentrates solely on the Polish merger market, legal consolidation procedure is described in section 2 . This section also presents collected data about merger transactions executed on Polish market and results of the volume trend analysis. The article ends with some conclusions and suggestions for future research.

\section{Aggregate size measures of merger and acquisition market}

Every single merger and acquisition deal consists of the recurrent steps which should be always executed in order to maximize the probability that expected financial and operational synergies will emerge and the entire transaction will be recognized as successful.

Many authors like DePamphlis (2005: 131-252), Frąckowiak (2009: 49-51),
Herdan (2008: 29-46), lannotta (2010: 121-126) or Zadora (2011: 217-263) group all these steps into preliminary, transaction and integration phases. Preliminary phase can be understood as the stage when the potential counterpart is found and the formal contacts are established. Negotiations and legal consolidation form transaction phase. Once the deal is registered, integration activities start which initiate the synchronization and optimization of the organizational and business processes of the counterparts involved in the deal.

Furthermore, Boone and Mulherin (2007: 848-850; 2009: 28-30) as well as Denis and Macias (2013: 822-824) divide additionally the merger or acquisition sale process into the private and public phase. Following their terminology, the private merger and acquisition process can be defined as the period from the private initiation to the first public announcement of the transaction. Analogically, the public merger and acquisition process is the period from the first public announcement to the resolution of the merger. Figure 1 illustrates this division.

Boone and Mulherin (2007: 848850; 2009: 30) and Denis and Macias (2013: 822-824) mention that the cutoff date between both phases is defined as the day when the draft terms of merger (or the definite agreement in case of the acquisition) is publicly announced. This allows assigning the preliminary phase and negotiation sub-phase to the private part of the merger and acquisition process and limiting its public part to the legal consolidation sub-phase. The integration phase is not included because it starts right after the resolution of the deal.

Figure 2 summarizes phases mapping between both definitions of the merger and acquisition process. The proposed mapping holds in the situation 


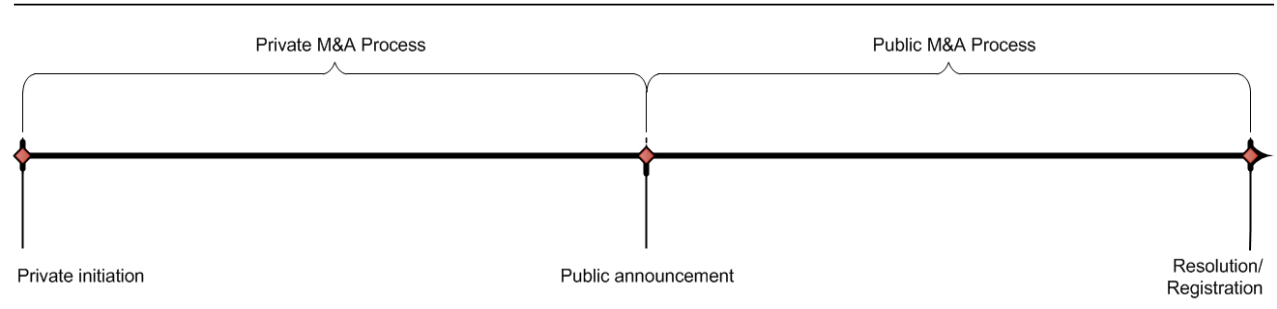

Fig 1. Merger and acquisition process diagram.

Source: authors' study.

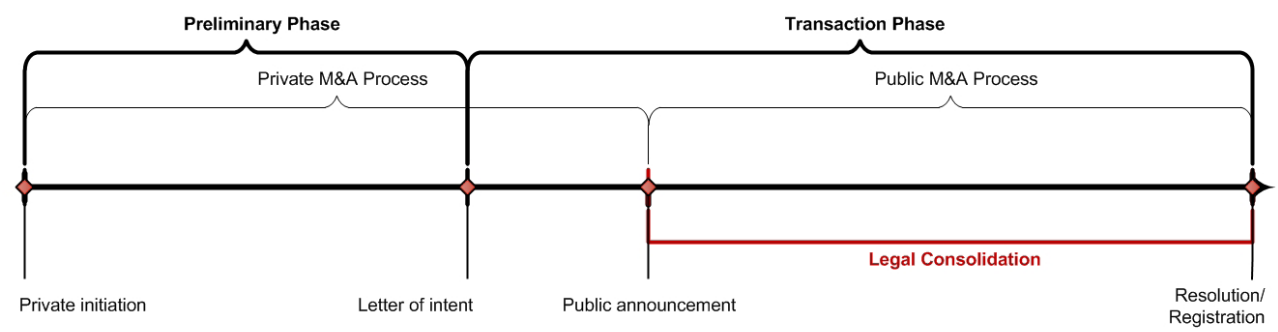

Fig 2. Merger and acquisition process definitions mapping.

Source: authors' study.

when the stipulation of the final agreement and its public announcement happen in the short timeframe. Additionally, Boone and Mulherin (2007: 848-850) highlight that sometimes the potential transaction is mentioned in the financial media before the final agreement is signed (so called rumor day). In this situation the negotiation sub-phase cannot be classified as a fully private part of the merger process.

Public merger and acquisition process together with its initialization, completion or withdrawal announcement events allows defining the following merger and acquisition market measures:

- Announced Volume (AV) - number or monetary value of transactions publicly announced in a predefined time interval (e.g. month, quarter or year) in a given geographical territory.

- Completed Volume (CV) - number or monetary value of transactions officially finalized in a predefined time interval in a given geographical territory.

- Backlog Volume (BV) - number or monetary value of transactions publicly announced in the past and still not completed. This measure is often calculated as of given day.

- Withdrawn Volume (WV) - number or monetary value of transactions which were withdrawn in a predefined time interval in a given geographical territory.

These four merger and acquisition measures are interconnected with each other with the following relation: 


$$
\Delta B V t=A V \Delta t-C V \Delta t-W V \Delta t
$$

Equation (1) states that in the given time period the difference between backlog volumes measured at the beginning and ending of this time range is equal to the announced volume lessened by the completed and withdrawn volumes reported during this time range.

Merger and acquisition market size measures are often used to characterize market for corporate control in a given country or region. When they are calculated on large historical datasets covering vast span of time, it is possible to see that this market is clearly not constant in time as the periods with intense merger and acquisition activity are followed by the ones with rather moderate activity. In literature this economic phenomenon is widely investigated and known as merger and acquisition waves1.

Pryor (2001: 825-840) and Perepeczo (2010: 21-36) analyze these waves on global markets across all industries while Brakman et al. (2006: 4-28) narrow their research to global cross border merger and acquisition transactions. Netter et al. (2011: 2316-2357) and Brealey et al. (2011: 814-815) investigate merger and acquisition historical patterns in United States. Similar research for European region is performed by Campa and Moschieri (2008: 1-33; 2009: 74-84).

Above authors make an attempt to provide a synthetic view on merger and acquisition waves as they do not concentrate on smaller regions or single industries. More granular industry-specific articles are written for example by Jaworska (2013: 58-69), Lemkowska (2009: 3-16) and Walter (2004: 42-47). They concentrate on agriculture industry,

\footnotetext{
${ }^{1}$ Author of this article has decided to present a literature review which consists of the articles published in year 2000 or later.
}

insurance sector and financial services, respectively.

From the other hand, country-specific research is performed by Cernat-Gruici et al. (2010: 167-178) who decide to look solely at Romanian merger and acquisition market. Filipovic et al. (2012: 34-39) extend the geographical range to southeast Europe by analyzing not only Romania, but Croatia and Bulgaria as well. Halmos (2008: 65-69) shows current trends present on Hungarian market and compares them with the situation in Central Europe and entire world. In turn, Polish market for corporate control is a main research scope for Bącal and Bem (2014: 726-729), Frąckowiak (2009: 52-66), Janowicz (2012: 67-86) and Lewandowski (2001: 12-54).

Completed volume is used as main merger and acquisition market size measure by nearly all the authors mentioned in the previous four paragraphs. Only Brakman et al. (2006: 5) rely on announced volume instead of completed volume while Campa and Moschieri (2008: 17; 2009: 7576) apply both measures for European merger and acquisition market. In turn, Cernat-Gruici et al. (2010: 169-171) calculate additionally backlog and withdrawn volumes and as a consequence provide a complete size overview of Romanian merger and acquisition market.

Apart from the literature, merger and acquisition market size measures are vastly used in commercial research done by investment banks and consultancy companies. The level of merger and acquisition activity is often assessed by equity research teams specializing in capital markets as it gives a good indication about the expected revenues of the bulge bracket and boutique advisory firms which participate in the majority of transactions (Credit Suisse (2010: 3-11) and J.P. Morgan (2009: 3-16)). What is 
Table 1 Comparison of the events definitions.

\begin{tabular}{|c|c|c|c|}
\hline Date Type & Thomson Reuters & Dealogic & EMIS \\
\hline Announcement & $\begin{array}{c}\text { The date when one or } \\
\text { more parties involved } \\
\text { in the transaction } \\
\text { makes the first public } \\
\text { disclosure of common } \\
\text { or unilateral intent to } \\
\text { pursue the transaction } \\
\text { (no formal agree- } \\
\text { ment is required). }\end{array}$ & $\begin{array}{c}\text { The first date on } \\
\text { which the full terms } \\
\text { of a transaction are } \\
\text { officially announced, } \\
\text { or a price, price } \\
\text { range, or valuation, is } \\
\text { announced by one of } \\
\text { the parties concerned. }\end{array}$ & $\begin{array}{c}\text { The earliest date } \\
\text { in which the trans- } \\
\text { action was publicly } \\
\text { announced. }\end{array}$ \\
\hline Completion & $\begin{array}{c}\text { The date when the en- } \\
\text { tire transaction is com- } \\
\text { pleted and effective. }\end{array}$ & $\begin{array}{c}\text { The date on } \\
\text { which a transaction is } \\
\text { completed or declared } \\
\text { wholly unconditional } \\
\text { by one of the principal } \\
\text { parties involved. }\end{array}$ & $\begin{array}{c}\text { A transaction is offi- } \\
\text { cially announced as } \\
\text { finalized and com- } \\
\text { pleted by either of } \\
\text { the party involved. }\end{array}$ \\
\hline Withdrawn (Failed) & $\begin{array}{c}\text { The date when } \\
\text { the transaction is } \\
\text { terminated, with- } \\
\text { drawn, expires or } \\
\text { becomes otherwise } \\
\text { unsuccessful. }\end{array}$ & $\begin{array}{c}\text { The date when the } \\
\text { transaction takeover } \\
\text { bid is withdrawn, } \\
\text { rejected or the } \\
\text { offer has expired. }\end{array}$ & $\begin{array}{c}\text { The date when the } \\
\text { transaction is can- } \\
\text { celled or called off. }\end{array}$ \\
\hline
\end{tabular}

Source: DealWatch Documentation, Official M\&A Ranking Criteria 2013, Thomson Reuters Definitions.

more, the Big Four companies2 issue reports in which they summarize the current situation on the merger and acquisition market (often narrowed to a given industry or region) and present their outlook for the shortterm future. In the past Polish merger and acquisition market was assessed in such a way by EY (2013: 1-4) and KPMG (2010: 9-18; 2010a: 6-10).

Announcement, completion and withdrawn events

All the authors except Campa and Moschieri (2008: 36-37; 2009: 86) mentioned in the previous literature review do not provide at all any

$\overline{2}$ The Big Four is formed by Deloitte, EY, PwC and KPMG companies which are the four largest international professional services networks. They offer audit, assurance, tax, consulting, advisory, actuarial, corporate finance and legal services. definitions of the announcement, completion and withdrawn dates. However, majority of them (Brakman et al. (2006: 3-4), Cernat-Gruici et al. (2010: 169-177), Frąckowiak (2009: 56-58), Lewandowski (2001: 15), Netter et al. (2011: 2320-2324), Pryor (2001: 826-827), Walter (2004: 4247)), rely on the datasets provided by Thomson Reuters which is the global commercial data vendor. That is the reason why such definitions can be deducted from the database fields' descriptions.

Table 1 summarizes the most important date fields available in Thomson Reuters database and compares them with the analogical ones from two different commercial databases owned by Dealogic and EMIS3 data providers.

3 EMIS (formerly known as ISI Emerging Markets) concentrates on providing critical information and research on emerging markets. That is why scientific and commercial merger and acquisition 
The presented date definitions are very general in order to cover the wide universe of the merger and acquisition transaction techniques. They are predominantly based on the public disclosure (foreign language news media, filings at the US Securities and Exchange Commission and its international counterparts or trade publications) of the information by the entities involved in the transaction.

Using broad date definitions from commercial data vendors has significant drawbacks. All the events associated with these dates happen shortly before or during the second transaction phase of the merger and acquisition process (please refer to fig. 2). However, it is possible that for one deal the public announcement of the intent to pursue the transaction may take place with the stipulation of letter of intent (the whole phase is covered), for the other transaction it could be the day when the draft terms of merger (definitive agreement in case of acquisitions) is approved and signed (only legal consolidation sub-phase is covered then). In the extreme case when the transaction had been kept secret and not publicly announced till the time it was completed, announcement and completion dates are the same. Actually, it is the case reported by Campa and Moschieri (2008: 3, 22; 2009: 77). They mentioned that around $33 \%$ of the analyzed sample of European mergers and acquisition was announced on the completion date4. Similar sample percentage $(38 \%)$ of such transactions was re-

research focusing on Central and Eastern Europe (Halmos (2008: 67), EY (2013: 1), KPMG (2010: 7, 2010a: 11)) is based on its datasets.

4 Their research reveals that completion upon announcement occurs mainly in smaller deals. This announcement strategy is also much more likely in open market purchases and in private deals than in public offers. It is also more ported by Brakman et al. (2006: 5). Shifts of the public announcement event within transaction phase of the merger and acquisition process cause that reported announced and backlog volumes may be inaccurate.

What is more, adopted commercial vendor definitions often do not comply with scientific research assumptions. Netter et al. (2011: 2320-2323) highlight that the type of transaction of research interest may not match with the definitions in a data source and that in general the data providers do not reveal in what way the data is collected causing that the researcher cannot determine if their classification is suitable for his or her research.

Additionally, Netter et al. (2011: 23202323) point out that it is little certainty on the degree to which Thomson Reuters database is complete. They refer to several works which show the data inconsistencies in the domestic (United States) transactions. Also, they state that they cannot suggest anything about the completeness of the data regarding the foreign transactions. Similar concerns were addressed by Pryor (2001: 826-827) and Halmos (2008: 67). The latter one draws such conclusions after the comparison of two databases, namely EMIS and UNCTAD FDI.

\section{Polish merger market case study}

Previous section was an attempt to define various merger and acquisition measures. They can be understood as an aggregation statistics applied on the single transaction level in a given time period. Their accuracy and consistency is assured when the public announcement of the deal, its completion or withdrawal happen in the same stage of the merger and acquisition process for every considered transaction.

popular in continental Europe, especially in Germany. 
Literature review revealed that this is not possible when the research is based on the data coming from the commercial providers as their date definitions are too generic.

The main scope of the empirical part of this article is to analyze solely Polish merger market. Acquisitions are intentionally excluded. The main difference between both transaction types can be seen in their legal consolidation phase (Buczek and Mercik 2015: 599). In case of the merger, the company which is taken over will cease to exist at the end so all its assets and liabilities are transferred to the acquiring company or newly formed one. From the other hand, acquisition does not have such significant impact on the legal existence of the company being acquired as only its ownership structure changes depending on the percentage stake bought - the company itself still exists, at least from the legal point of view.

The cessation of company being acquired in the merger transaction causes that its legal consolidation phase needs to be more formalized compared to the acquisition transaction.

European Union legislation consists of two separate directives which regulate transaction counterparts' legal consolidation. Domestic legal mergers are considered in the directive 2011/35/EU of 5th April 2011 (2011: 1-11) while cross-border legal mergers are the main subject of the directive 2005/56/EC of 26th October 2005 (2005: 1-9). The first directive superseded the initial directive 78/855/EEC of 9th October 1978 (1978: 36-43), in order to ensure the clarity and rationality of the legislation, which has been amended substantially several times over the years.

These two directives formed one general framework for legal merger consolidation for every European Union member country. Their provisions are present in Polish legislation in
The Code of Commercial Partnerships and Companies (Kodeks Spółek Handlowych 2000: 127-144) in the articles 491-527.

\section{Legal merger framework}

Legal merger consolidation can be executed as a merger by takeover or merger by formation of a new company (Kodeks Spółek Handlowych 2000: 128). The former approach should be understood as transfer of all assets of a company or partnership (the target one) to another company (the bidding one) in exchange for the shares that the bidding company issues to the shareholders or partners of the target company or partnership. In turn, the latter one assumes the formation of a company to which the assets of all merging companies or partnerships devolve in exchange for shares of the new company.

Both procedures differ in the way the assets are exchanged for the shares but they still have many common elements which are presented in the order of appearance in fig. 3 .

Detailed description of the consecutive procedure stages can be found in Buczek and Mercik (2015: 599-600). However, it is clearly visible that announcement events (elements 2 and 8 from fig. 3) are the most important elements present in this consolidation procedure in the context of merger market size measurement.

These obligatory announcements are almost always 5 posted in The Journal of the Ministry of Justice (Monitor Sądowy i Gospodarczy 1995: 3). They allow redefining market size measures in the following way:

- Announced Merger Volume (AMV) - number or monetary value of

\footnotetext{
5 Please refer to The Code of Commercial Partnerships and Companies (Kodeks Spółek Handlowych 2000: 131, 135-136, 142 ) for the announcement exceptions.
} 


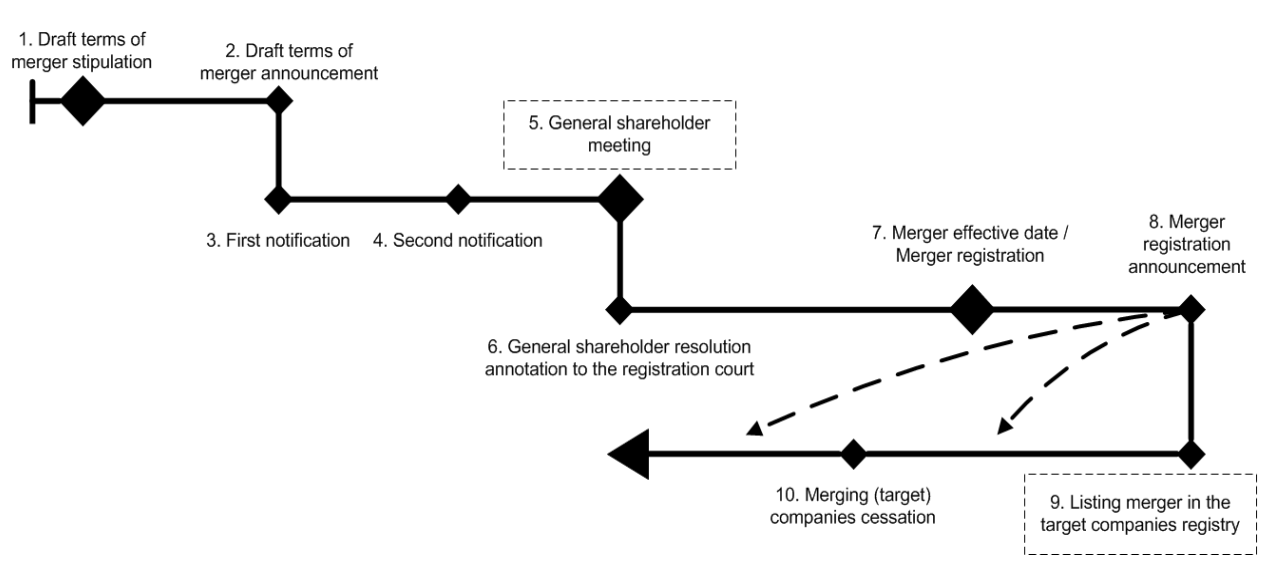

Fig 3. Legal merger procedure.

Source: Buczek and Mercik 2015: 599.

merger transactions which draft terms of merger was announced in The Journal of the Ministry of Justice in a predefined time interval (e.g. month, quarter or year).

- Completed Merger Volume (CMV) - number or monetary value of merger transactions which registration was announced in The Journal of the Ministry of Justice in a predefined time interval.

- Backlog Merger Volume (BMV) number or monetary value of merger transactions which draft terms of merger was announced in The Journal of the Ministry of Justice in the past but its registration has still not been announced in this journal.

Above market size measures adopt the same procedure elements which are used by Buczek and Mercik (2015: $600)$ to measure public legal merger time to completion.

Unfortunately, legal merger consolidation framework presented in fig. 3 and introduced by The Code of Commercial Partnerships and Companies (Kodeks Spółek Handlowych 2000: 127-144) does not impose any announcement obligation in the situation when the transaction is cancelled and not recorded in the National Court Register. Thus, this legal construction has twofold negative consequences on measuring merger market size. Firstly, it is impossible to define withdrawn merger volume (WMV) because withdrawal announcement event is not defined. Secondly, failed transactions for which draft terms of merger was already announced will be always classified as pending transactions and will be taken into consideration while calculating merger backlog volume. Fortunately, announced and completed merger volumes are not affected by this legal definition shortage.

\section{Dataset description}

As mentioned before, the draft terms of merger and registration announcements are always posted in The Journal of the Ministry of Justice (Monitor Sądowy i Gospodarczy 1995: 3). That is the reason why this journal should be seen as the most complete and reliable source of the information about Polish merger market. 
Table $\mathbf{2}$ Transaction specific information.

\begin{tabular}{|c|c|c|c|c|}
\hline \multicolumn{3}{|c|}{ Transaction Status } & \multicolumn{2}{c|}{ Number of counterparts } \\
\hline Announced & Pending & Completed & Two & More than two \\
\hline 3870 & 299 & 3571 & 3271 & 599 \\
\hline
\end{tabular}

Source: authors' study.

Table 3 Counterpart specific information.

\begin{tabular}{|c|c|c|c|c|c|c|}
\hline \multirow{2}{*}{ Counterpart } & \multicolumn{3}{|c|}{ Legal form } & \multicolumn{2}{c|}{ Stock market } & \multirow{2}{*}{ Total } \\
\cline { 2 - 6 } & $\begin{array}{c}\text { Joint- } \\
\text { stock }\end{array}$ & $\begin{array}{c}\text { Limited } \\
\text { liability }\end{array}$ & Other & Listed & Unlisted & \\
\hline $\begin{array}{c}\text { Acquiring } \\
\text { company }\end{array}$ & 1230 & 2639 & 1 & 268 & 3602 & 3870 \\
$\begin{array}{c}\text { Company being } \\
\text { acquired }\end{array}$ & 772 & 4306 & 63 & 30 & 5111 & 5141 \\
\hline
\end{tabular}

Source: authors' study.

The journal allowed collecting the information about 3870 merger transactions which have taken place in the period between 1st January 2002 and 31st December 2013.

Draft terms of merger announcement date, merger registration date as well as its announcement, number of counterparts and transaction status are all transaction specific information which has been collected.

National Court Register contains 3571 completed transactions while for 299 transactions registration event was not reported till 31st December 2013. Among 3870 transactions, 85 percent consists of only two counterparts - acquiring company and company being acquired. At least one additional company being acquired participates in the remaining 15 percent of transactions. The dataset was enhanced with the merging companies' characteristics:
KRS identification number6, company name, legal form and initial capital level. Additionally, the presence on the Warsaw Stock Exchange (WSE) and NewConnect7 at the time of the draft terms of merger announcement was verified for every counterpart involved in a given transaction.

Table 3 reveals that collected sample is diversified and contains different types of companies. The prevailing majority of companies (97\%) are private companies which are not present on any stock exchange. If the company is public, it is more probable that it acts as an acquiring company in the

6 National Court Register (pol. Krajowy Rejestr Sądowy - KRS).

7 It is an alternative stock exchange in Poland designated for smaller companies with simplified entrance criteria and limited reporting requirements. 


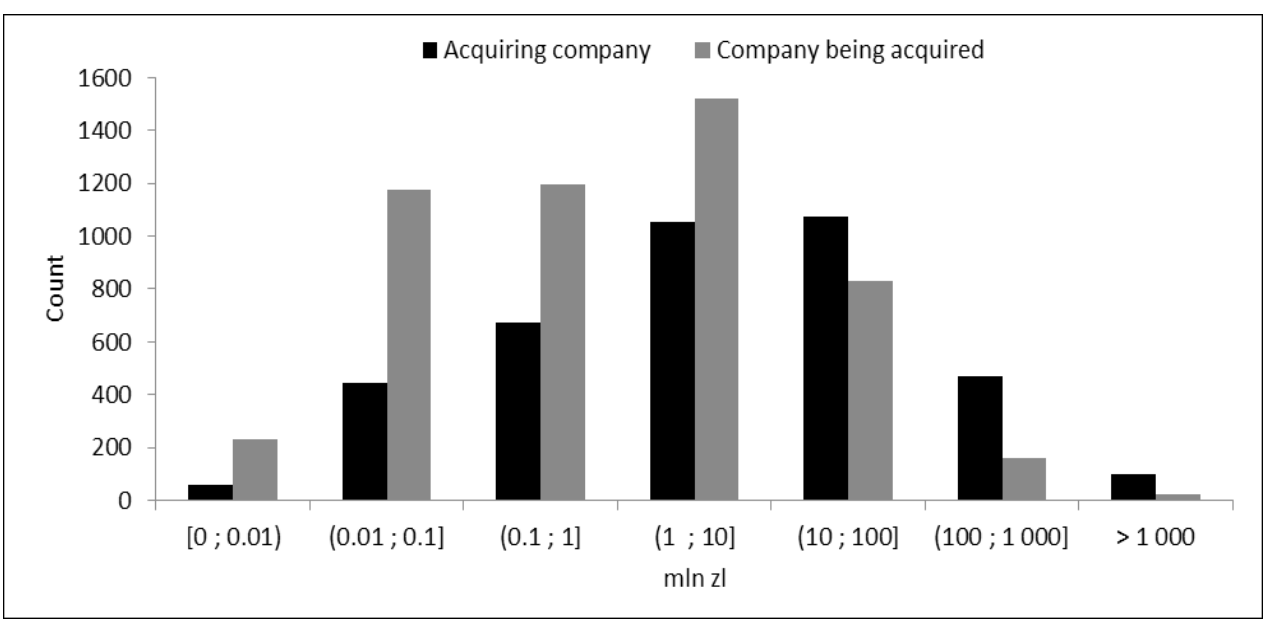

Fig 4. Merging companies initial capital levels.

Source: authors' study.

transaction. There are 268 acquiring companies and only 30 companies being acquired which are listed on a stock exchange.

Limited liability company is the most common legal form for both types of counterparts taking part in the deal as 2639 acquiring companies have such legal construction against 4306 companies being acquired. Jointstock companies are more often on the buy side than on the sell side of the transaction. General partnerships, limited partnerships, limited joint-stock companies and foreign enterprise branches are other legal forms of companies which appeared in the sample8. Their legal construction is more simple and general in comparison with limited liability and joint-stock companies and intended for running smaller scale businesses.

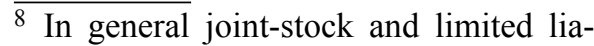
bility companies are the most popular enterprise legal forms to run a business in Poland.
That is the reason why these kinds of companies do not merge often, their share in the sample is marginal and well below 0.01 percent. And even if they do, they are nearly always target counterparts in the transaction. The prevalence of private enterprises cause that the market value of the majority of transactions cannot be determined. For this reason, the author of this article has decided to express transaction size as the sum of the initial capital of merging companies at the time when the draft terms of merger was announced. Initial capital level is always disclosed in the National Court Register for jointstock and limited liability companies. By definition initial capital is not established in other considered legal forms of companies. Author of this article has assumed in these cases that initial capital is equal to 0 .

Figure 4 displays initial capital distribution of all merging entities in the sample. It is clearly visible that in general acquiring companies are bigger 
than companies being acquired as the former ones dominate in higher level ranges of the initial capital while the latter ones have a stronger footprint in respective lower ranges. The dataset quality is very high because announcement obligations imposed by Polish legislation guarantee the every merger transaction is recorded. Moreover, the draft terms of merger and registration announcements definitions are well defined and concordant with research assumptions. Announcement events take place at the same merger phase of every transaction causing that the dataset is consistent - for every completed transaction draft terms of merger announcement happen at least couple of weeks earlier than registration announcement. Thus, the choice of The Journal of the Ministry of Justice as a main information source about Polish merger market eliminates research limitations associated with the datasets provided by the commercial vendors (please refer to the subsection 1.1).

\section{Merger volumes in Poland}

Figure 5 presents announced, backlog and completed merger volumes calculated by the calendar quarters between first quarter of 2002 and fourth quarter of 2013. Potential withdrawn volume is included in the backlog volume (please refer to the subsection 2.1 for the explanation). Volumes are expressed as deal count or total value ( $\mathrm{mln} \mathrm{zl}$ ) being merging companies' initial capital sum.

It is worth nothing that deal count is more stable measure in comparison with total value as it is not influenced strongly by so called mega deals. For example, the biggest peaks which appeared in first, second and third quarter of 2010 for announced, backlog and completed merger volumes are the result of increased consolidation activity in Polish energy sector. In 2010, PGE Polska Grupa Energetyczna and Tauron Polska Energia were consolidating their holding structure.

Moreover, quarterly peak shift between announced and completed volume is directly related to the legal merger time to completion analyzed by Buczek and Mercik (2015: 602606). They state that on average it takes 4.5 month to complete the consolidation procedure from the draft terms of merger stipulation to the registration announcement. This time to completion corresponds well with observed peak shifts even though announced volume is measured at the draft terms of merger announcement, not its stipulation.

Starting from 2002 both announced and completed merger volumes were steadily improving in Poland to reach their global peaks in the fourth quarter of 2010 and 2011, respectively. In the next quarters merger activity has weakened. When looking at the merger backlog volume, it can be observed that its erosion started after third quarter of 2011 and was the most intensive in 2012. This process reverted in the second quarter of 2013. This rebound suggests that in the upcoming year 2014 completed merger volume levels should be higher than in 2013.

\section{Conclusions}

Announced, backlog, completed and withdrawn volumes are four quantitative measures which allow assessing the size of a given merger and acquisition market. All these measures are based on the announcement events which initialize and terminate public phase of the merger and acquisition process. Thus, all the transactions which are not publicly 

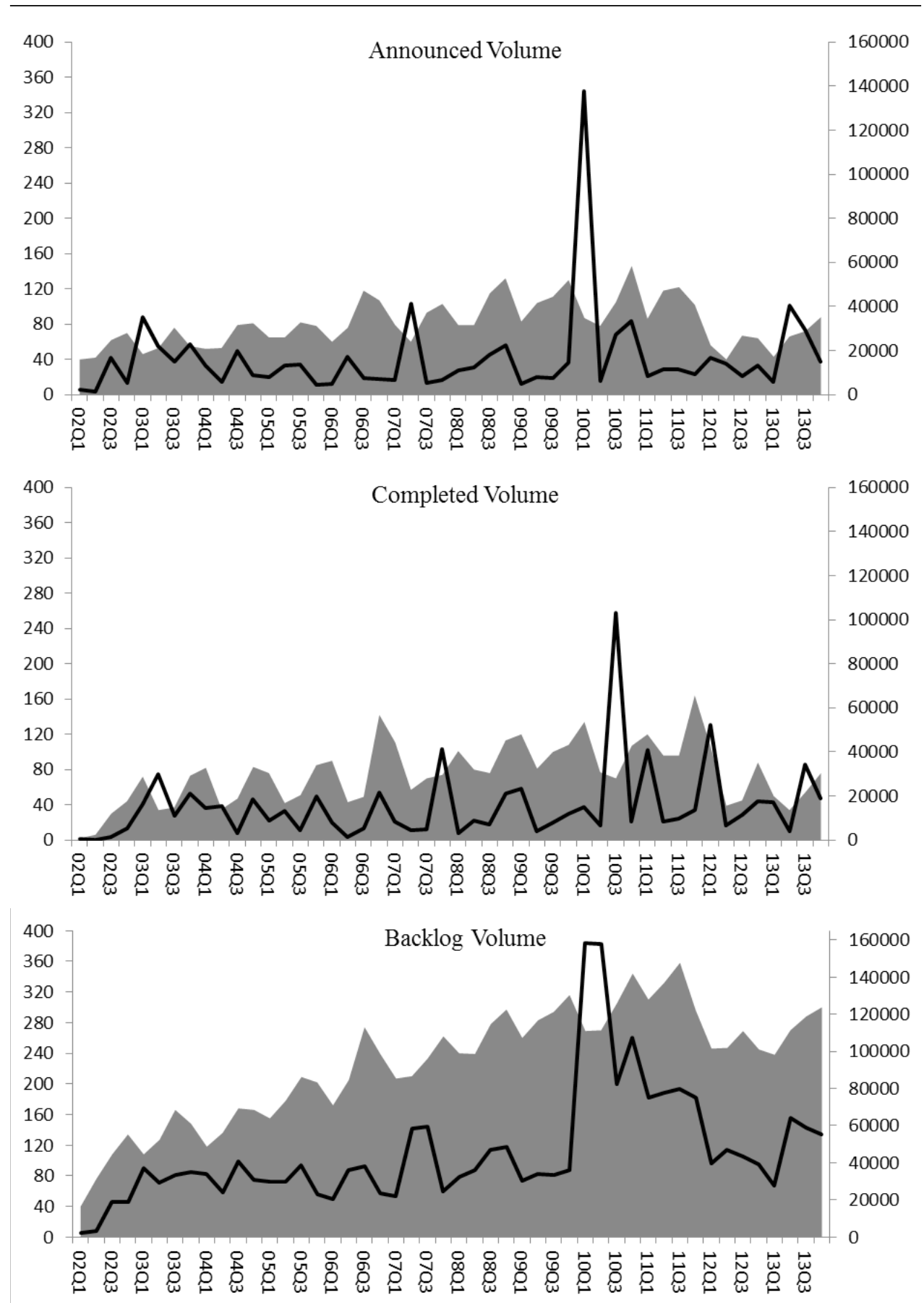

Deal Count (left axis) - Total Value in mln zl (right axis)

Fig 5. Announced, completed and backlog merger volume by quarter. 
announced are not taken into the consideration.

The authors of the scientific and commercial publications reviewed in the section 1 of this article assess the size of a chosen merger and acquisition market by calculating respective volumes on the datasets which are provided by commercial data vendors like Thomson Reuters, EMIS or Dealogic. This approach has its limitations as it does not guarantee that required announcements happen at the same stage of the merger and acquisitions process for every single transaction, research assumption may not comply with commercial vendors' data collection methodology or some transactions may not be recorded at all in their databases.

In order to overcome these limitations, the author of this article decided to construct his research assumptions in concordance with legal merger consolidation procedure defined in The Code of Commercial Partnerships and Companies (Kodeks Spółek Handlowych 2000: 127-144). This approach allowed creating merger transactions dataset consisting of 3870 domestic mergers in Poland completed between 2002 and 2013. This dataset is not biased with limitations described in the previous paragraph. Moreover, it is well diversified as it consists of public and private companies which have different legal forms.

Announced, backlog and completed volumes have been calculated quarterly on the collected data for Polish merger market. All these quantitative measure exhibit strong seasonality. Besides, their stable growth on Polish market was observed from 2002 till 2011. After 2011 this trend has reverted, but rebound of the backlog volume in the second quarter of 2013 suggests that at least completed volume levels should be higher in the upcoming quarters.
At this point, future research should be concentrated on finding the cause of the observed fluctuation of merger activity in Poland. Following Harford (2005: 532-536) two research streams should be considered, namely: neoclassical and behavioral view. The former one assumes that merger waves are driven by an economic disturbance that leads to industry reorganization while the latter states that strong correlation exists between stock valuation and merger activity. Theoretical model which reflect neoclassical assumptions is built by Jovanovic and Rousseau (2002: 198-203). In turn, proposal of behavioral model can be found in Shleifer and Vishny (2002: 297-304) and Rhodes-Kropf and Viswanathan (2004: 2690-2709). Moreover, empirical econometrics models combining both views are developed for example by Choi and Jeon (2011: 241-247), Gugler et al. (2012: 6-14) or Harford (2005: 544-547).

This article was an attempt to characterize domestic Polish merger market. However, international research scope should be still possible as merger market size measures are based on the definitions concordant with European Union legislation. Legal consolidation procedure in Polish law is a direct transposition of the directives 2011/35/EU and 2005/56/EC of the European Parliament. Additionally, potential research in this domain should also concentrate on improving merger backlog volume calculation as it currently contains all the transactions which have been withdrawn in the past. In this case confidence intervals calculated on legal merger time to completion could be a good statistical approach to separate these withdrawn transactions from the pending ones as the legal consolidation procedure itself does not impose any announcement obligation in the situation when the transaction will not be completed. 


\section{Bibliography}

Ustawa z dnia 15 września 2000 r. Kodeks spółek handlowych.

Ustawa z dnia 22 grudnia 1995 r. o wydawaniu Monitora Sądowego i Gospodarczego.

Capital Markets Monthly (2010) Credit Suisse, https://research-and-analytics. csfb.com/ [05.11.2015].

Central and South Eastern Europe M\&A Barometer 2013 (2013) Ernst and Young, http://www.ey.com/Publication/vwLUAssets/MA_Barometr_ CSE/\$FILE/MA\%20Barometer_CSE_2013_Final_checked_03\%2012.pdf [05.11.2015].

DealWatch Documentation, EMIS, http://www.securities.com/emis/professional [05.11.2015].

Directive 2005/56/EC of the European Parliament and of the Council of 26 October 2005 on cross-border mergers of limited liability companies, Official Journal of European Communities, no. L 310/1.

Directive 2011/35/EU of the European Parliament and of the Council of 5th April 2011 concerning mergers of public limited liability companies (codification), Official Journal of European Union, no. L 110/1.

Rynek fuzji i przejęć. Polska na tle Europy Środkowo-Wschodniej. I półrocze 2010 (2010) KPMG and DealWatch Research, https://www.kpmg.com/PL/ pl/IssuesAndInsights/ ArticlesPublications/Documents/Rynek-fuzji-i-przejec-Polska-na-tle-Europy-Srodkowo-Wschodniej.pdf [05.11.2015].

Rynek fuzji i przejęć. Polska na tle Europy Środkowej. Edycja 2010 (2010a) KPMG and DealWatch Research, https://www.kpmg.com/PL/pl/IssuesAndInsights/ArticlesPublications/
Documents/Rynek-fuzji-przejec.-Polska-na-tle-Europy-Srodkowej.pdf [05.11.2015].

Official M\&A Ranking Criteria 2013, Dealogic Holdings plc, http://www. globalcapital.com/ /media/45d06f7fdb62458da825367c35472ef7.pdf [05.11.2015].

The era of globalized M\&A. Winds of change (2009) JPMorgan and Thomson Reuters, https://www.jpmorgan.com/ $\mathrm{cm} /$ BlobServer/The_era_of_globalized_M_and_A.pdf?blobkey=id\&blobwhere $=1158542185915 \&$ blobheader=application/pdf\&blobheader name1=Cache-Control\&blobheader value $1=$ private $\&$ blobcol=urldata $\&$ blobtable=MungoBlobs [05.11.2015].

Third Council Directive 78/855/EEC of 9 October 1978 based on Article 54 (3) (g) of the Treaty concerning mergers of public limited liability companies, Official Journal of European Communities, no. L 295/36.

Thomson Reuters Definitions, Thomson Reuters, http://mergers.thomsonib.com/DealsWeb/ help/def.htm [05.11.2015].

Bącal G. and Bem J. (2014) Charakterystyka polskiego rynku fuzji i przejęć oraz perspektywy jego rozwoju, Zeszyty Naukowe Uniwersytetu Szczecińskiego. Finanse, Rynki Finansowe, Ubezpieczenia, no. 67, pp. 725-737.

Boone A.L. and Mulherin J.H. (2007) How Are Firms Sold?, The Journal of Finance, vol. 62, no. 2, pp. 847-875.

Boone A.L. and Mulherin J.H. (2009) Is There One Best Way to Sell a Company? Auctions Versus Negotiations and Controlled Sales, Journal of Applied Corporate Finance, vol. 21, no. 3, pp. 28-37. 
Brakman S., Garretsen H. and van Marrewijk C. (2006) Cross-Border Mergers \& Acquisitions: the Facts as a Guide for International Economics, CESifo Working Paper, no. 1823, pp. 1-36.

Brealey R.A., Myers S.C. and Allen F. (2011) Principles of Corporate Finance, McGraw-Hill Irwin, New York.

Buczek A. and Mercik J. (2015) On conformance of legal merger duration with Burr type III and XII distribution, The Wroclaw School of Banking Research Journal, vol. 15, no. 5, pp. 597-608.

Campa J.M. and Moschieri C. (2008) The European M\&A Industry: Trends, Patterns and Shortcomings, Working Paper WP-762, IESE Business School University of Navarra.

Campa J.M. and Moschieri C. (2009) The European M\&A Industry: A Market in the Process of Construction, Academy of Management Perspectives, vol. 23 , no. 4, pp. 71-87.

Cernat-Gruici B., Constantin L.G. and lamandi I.E. (2010) An Overview on the Romanian M\&A Market during the Recent Financial Crisis, The Romanian Economic Journal, vol. 13, no. 37, pp. 167-178.

Choi S.H. and Jeon B.N. (2011) The impact of the macroeconomic environment on merger activity: evidence from US time-series data, Applied Financial Economics, vol. 21, no. 4, pp. 233-249.

Denis D.J. and Macias A.J. (2013) Material Adverse Change Clauses and Acquisition Dynamics, Journal of Financial and Quantitative Analysis, vol. 48, no. 3, pp. 819-847.

DePamphilis D. (2005) Mergers, Acquisitions, and Other Restructuring Activities. An Integrated Approach to Process, Tools, Cases, and Solutions, Elsevier, San Diego.

Filipović D., Podrug N. and Prester J. (2012) Cross-border Mergers and Acquisitions in Southeast Europe: Cases from Croatia, Romania and Bulgaria, International Journal of Management Cases, Special Issue: Corporate governance in Southeast Europe: in search for transparency and efficiency, vol. 14, pp. 32-40.

Frąckowiak W. (2009) Fuzje i przejęcia, Polskie Wydawnictwo Ekonomiczne, Warszawa.

Gugler K., Mueller D.C. and Weichselbaumer M. (2012) The determinants of merger waves: An international perspective, International Journal of Industrial Organization, vol. 30, no. 1, pp. 1-15.

Halmos K. (2008) Short theoretic Abstract of the M\&A activity and overview of the trends in Hungary from 2002 to 2008, Periodica Polytechnica Social and Management Sciences, vol. 16, no. 2, pp. 63-69.

Harford J. (2005) What drives merger waves?, Journal of Financial Economics, vol. 77 , no. 3, pp. 529-560.

Herdan A. (2008) Fuzje, przejęcia... Wybrane aspekty integracji, Wydawnictwo Uniwersytetu Jagiellońskiego, Kraków.

lannota G. (2010) Investment Banking. A Guide to Underwriting and Advisory Services, Springer-Verlag.

Janowicz M. (2012) Cykliczność fuzji i przejęć na świecie i w Polsce, Zeszyty Naukowe Uniwersytetu Szczecińskiego. Finanse, Rynki Finansowe, Ubezpieczenia, no. 54, pp. 67-86.

Jaworska M. (2013) Fuzje i przejęcia w przemyśle rolno-spożywczym na świecie w latach 1990-2012, 
Journal of Agribusiness and Rural Development, vol. 4, no. 30, pp. 59-69.

Jovanovic B. and Rousseau P. (2002) The Q-theory of mergers, American Economic Review, vol. 92, no. 2, pp. 198-204.

Lemkowska M. (2009) Cykl koniunkturalny a dynamika fuzji i przejęć na rynku ubezpieczeniowym - analiza teoretyczna, Wiadomości Ubezpieczeniowe, no. 4, pp. 3-16.

Lewandowski M. (2001) Fuzje i przejęcia w Polsce na tle tendencji światowych, WIG-Press, Warszawa.

Netter J., Stegemoller M. and Wintoki M.B (2011) Implications of Data Screens on Merger and Acquisition Analysis: A Large Sample Study of Mergers and Acquisitions from 1992 to 2009, The Review of Financial Studies, vol. 24, no. 7, pp. 2316-2358.

Perepeczo A. (2011) Fale fuzji i przejęć w latach 1990-2009 a kryzys finansowy, Zeszyty Naukowe Uniwersytetu Szczecińskiego. Finanse, Rynki
Finansowe, Ubezpieczenia, no. 39, pp. 21-36.

Pryor F.L. (2001) Dimensions of the Worldwide Merger Boom, Journal of Economic Issues, vol. 35, no. 4, pp. 825-840.

Rhodes-Kropf M. and Viswanathan S. (2004) Market Valuation and Merger Waves, The Journal of Finance, vol. 59, no. 6, pp. 2685-2718.

Shleifer A. and Vishny R.W. (2002) Stock market driven acquisitions, Journal of Financial Economics, vol. 70, no. 3, pp. 295-311.

Walter I. (2004) Mergers and Acquisitions in Banking and Finance. What Works, What Fails, and Why, Oxford University Press, New York.

Zadora H. (2011) Fuzje i przejęcia na rynku kapitałowym. Motywy, okoliczności i warunki oraz procedury, procesy i struktury, Wydawnictwo Uniwersytetu Ekonomicznego w Katowicach, Katowice.

\title{
Zagregowane miary wielkości rynku fuzji: charakterystyka rynku polskiego w latach 2002-2013
}

\begin{abstract}
Abstrakt
Transakcje fuzji i przejęć są bardzo ważnym zjawiskiem ekonomicznym, które często prowadzi do trwałych zmian w strukturze poszczególnych sektorów gospodarki. Część teoretyczna artykułu definiuje zagregowane miary wielkości pozwalające spojrzeć w sposób ilościowy na rynek fuzji i przejęć. Zaproponowano następujące cztery miary: wolumeny transakcji ogłoszonych, ukończonych, anulowanych i trwających oraz ustalono zależności między nimi. Ograniczenia badań opartych na komercyjnych bazach danych (na przykład Thomson Reuters) zostały również przedstawione w tej części artykułu. Alternatywna metoda zbierania danych została zaproponowana. Jest ona oparta na Kodeksie Spółek Handlowych i zapewnia wykonanie pełnowartościowych badań na temat rynku fuzji. Zgodnie z tym podejściem zebrano informacje na temat 3870 transakcji fuzji, które zostały przeprowadzone od 1 stycznia 2002 do 31 grudnia 2013 w Polsce. Kwartalne wolumeny transakcji ogłoszonych, trwających i ukończonych były podstawowymi miarami wykorzystywanymi podczas analizy. Wszystkie te miary wykazują mocną sezonowość. Ich stabilny
\end{abstract}


wzrost zaobserwowano w latach 2002-2011. Po 2011 ten trend się odwrócił. Jednakże odbicie wolumenu transakcji trwających w drugim kwartale 2013 sugeruje, iż przynajmniej wolumen transakcji ukończonych powinien być większy w nadchodzących kwartałach. 
